\title{
Article 20. Codes of Conduct, Guidelines and Best Practices and/or Standards
}

1. Each Party shall encourage, as appropriate, the development, update and use of voluntary codes of conduct, guidelines and best practices and/or standards in relation to access and benefit-sharing.

2. The Conference of the Parties serving as the meeting of the Parties to this Protocol shall periodically take stock of the use of voluntary codes of conduct, guidelines and best practices and/or standards and consider the adoption of specific codes of conduct, guidelines and best practices and/or standards.

Overview

ABS transactions involve a multitude of relationships between governmental, non-governmental and private-sector actors at different levels of governance and across jurisdictions. Albeit exemplary in the context of modern environmental law, ${ }^{1}$ this multitude of relationships also points to the limitations of a purely inter-governmental approach to ABS regulation and to the relevance of more informal, complementary tools for shaping common expectations and behavior of all stakeholders involved in ABs transactions.

In this context, Article 20 calls attention to the role of voluntary instruments in the implementation of the Protocol. The terms 'codes of conduct, guidelines and best practices and/or standards' may include self-regulation instruments adopted by research entities/associations, funders, users' groups, private enterprises and business associations, as well as good-practice advice elaborated by indigenous and local communities, NGOs, donors and others. These voluntary instruments will be particularly relevant for stakeholders interested in pioneering its implementation on the ground, including before the entry into force of the Protocol, and also to provide ideas for national ABs legislation and procedures. Several such voluntary instruments on ABs already exist. ${ }^{2}$

1 Morgera, Buck and Tsioumani, “Conclusions," op. cit., 515-516.

2 Greiber et al., Explanatory Guide, op. cit., 196 make reference to the International Plant Exchange Network's codes of conduct: "The International Plant Exchange Network (IPEN): An Instrument of botanic gardens to fulfil the ABs Provisions," University of Bonn, accessed 
After the development of domestic ABs frameworks, voluntary instruments may contribute to establish/maintain excellence in the conduct of institutions involved in ABs transactions, or serve to support compliance with national ABS frameworks, providing tools and guidelines to ensure respect of legally binding rules. $^{3}$ They may also provide standards targeted to ABS in specific sectors. ${ }^{4}$ Furthermore, voluntary instruments may be useful to address certain genetic resources that are outside the scope of the Protocol ${ }^{5}$ or to go otherwise beyond existing legal requirements. ${ }^{6}$ Best practice standards may also become relevant in ABS relationships between Parties and non-Parties to the Nagoya Protocol. ${ }^{7}$

The following sections will analyze the obligation for Parties, and the mandate for the Protocol's governing body contained in Article 20, in turn.

Article 20(1) creates, similarly to Article 19(1), a best-endeavor obligation for all Parties to support the development, update and use of voluntary ABS instruments unilaterally or collectively (in the context of bilateral or regional ABS frameworks, ${ }^{8}$ and at the multilateral level). ${ }^{9}$ This obligation entails removing obstacles to the development of such voluntary instruments and arguably providing incentives in that regard. Parties may have recourse to awarenessraising and capacity-building activities to this end. ${ }^{10}$ Adherence to voluntary instruments may be taken into account by Parties' national authorities at the stage of authorizing access to genetic resources ${ }^{11}$ and possibly by indigenous and local communities authorizing access to traditional knowledge, ${ }^{12}$ particu-

30 November 2013, <www.botgart.uni-bonn.de/ipen/criteria.html>; "ABs Management Tool," International Institute for Sustainable Development and Swiss Government, accessed 30 November 2013, <www.sib.admin.ch/en/nagoya-protocol/abs-managementtool/index.html >; and the Ethical BioTrade standard, managed by the Union for Ethical BioTrade. As to the latter, see Oliva, "Implications of the Nagoya Protocol," op. cit., 373.

3 Ibid., 195.

4 Chiarolla, Louafi and Schloen, "Analysis of the Relationship," op. cit., 119.

5 See this commentary on Article 3.

6 Oliva, "Implications of the Nagoya Protocol," op. cit., 383.

$7 \quad$ See this commentary on Article 24.

8 See this commentary on Article 4, section 3.

9 See this commentary on Article 26, section 2.

10 Nagoya Protocol Article 21(e). See this commentary on Articles 21-22.

11 See this commentary on Article 6, section 3.2.

12 See this commentary on Article 6, section 4, and Article 7. 
larly when these voluntary agreements constitute the basis for independent verification of compliance. ${ }^{13}$ Parties may also decide to submit information on voluntary instruments to the ABS Clearinghouse. ${ }^{14}$

In as far as voluntary instruments developed by users concern traditional knowledge and genetic resources held by indigenous and local communities, ${ }^{15}$ Parties are to act under Article 20(1) with the effective participation of the communities concerned, ${ }^{16}$ taking into consideration their customary laws, protocols and procedures. ${ }^{17}$ And as part of the obligation to carry out awarenessraising activities, Parties are to promote voluntary instruments in consultation with these communities. ${ }^{18}$ From a provider community's perspective, a community protocol, ${ }^{19}$ code of conduct or inter-community agreement (in case of shared traditional knowledge) could also serve as a voluntary instrument for the purposes of Article 20. In the case of long-standing ABs relationships, such voluntary instruments could also be developed in cooperation with privatesector users. ${ }^{20}$

\section{3}

\section{Mandate for the Protocol's Governing Body}

Like Article 19, the Protocol's governing body is tasked with the periodic stocktaking of voluntary initiatives. In line with Св рractice, the governing body will likely invite Parties on a periodic basis to submit reports of sectoral reviews and examples of voluntary instruments, synthesize this information and make it available through the ABs Clearinghouse.

As opposed to Article 19, the Protocol's governing body is also explicitly tasked to consider the adoption of specific voluntary instruments. Adoption of these instruments by the Protocol's governing body would increase their legitimacy ${ }^{21}$ due to the underlying intergovernmental consensus, in serving as official guidance for the interpretation and application of the Protocol. As endorsed by the Protocol's governing body, voluntary instruments could thus

\footnotetext{
13 Oliva, "Implications of the Nagoya Protocol," op. cit., 384.

14 Nagoya Protocol Article 14(3)(d). See this commentary on Article 14, section 4.

15 Nagoya Protocol Articles 5(2), 6(2) and 7.

16 UNDRIP Articles 19 and 32(2); ILO Convention No 169, Article 6(2); and fn. 54 in this commentary on Article 5.

17 Nagoya Protocol Article 12(1). See this commentary on Article 12, section 2.

18 Nagoya Protocol Article 21(e).

19 See this commentary on Article 12, section 2.1.

20 Oliva, "Implications of the Nagoya Protocol," op. cit., 384-385.

21 Oliva, "Implications of the Nagoya Protocol," op. cit., 385.
} 
come to represent 'subsequent practice in the application of the treaty which establishes the agreement of the $[\mathrm{P}]$ arties regarding its interpretation. ${ }^{22}$ It may also be possible for the governing body to recognize or endorse pre-existing and future domestic, transnational and multilateral ABs frameworks. ${ }^{23}$ That being said, the Protocol does not clarify whether such an assessment would be conducted by the Protocol's governing body, could require the establishment of an ad hoc process given the high number of standard contractual clauses to be examined, or even be a function that might be subsumed under the Protocol's compliance procedures and mechanisms. It also remains to be seen whether the Protocol's governing body would engage in ascertaining the compliance with the Protocol of voluntary instruments that have been intergovernmentally approved in other fora, ${ }^{24}$ and what would be the fate of those instruments that are considered non-compliant. ${ }^{25}$

Overall, similarly to Article 19, this provision seeks to tap into normative activities undertaken by various ABS stakeholders such as indigenous and local communities, the research community, the private sector and NGOs at the national (but also sub-national and transnational) level(s) as a bottomup source of inspiration for discussions on ways to facilitate implementation of the Protocol at the multilateral level. ${ }^{26}$ In particular, voluntary instruments may arguably prove to be a useful basis to find agreement on difficult issues arising from the implementation of the Protocol, such as the distinction between commercial and non-commercial research, ${ }^{27}$ by taking into account actual experiences in scientific research collaborations, including those working in public domain-like conditions (i.e., without any ownership claims that would restrict access and use of the research results and basic research materials). ${ }^{28}$

22 VCLT, Article 31(3)(b).

23 Chiarolla, Louafi and Schloen, “Analysis of the Relationship," op. cit., 118.

24 This may be the case of intergovernmentally approved guidelines targeting non-State actors: see discussion in the context of the CGRFA in this commentary on Article 4, section 4.4 .

25 We are grateful to Geoff Burton for a useful exchange of ideas on this point.

26 Morgera, Buck and Tsioumani, "Introduction," op. cit., 10.

27 Pursuant to Nagoya Protocol Article 8(a). See this commentary on Article 8, section 2.

28 Dedeurwaerdere et al., “Governing Global Scientific Research,” op. cit., 419-420. 